\title{
Patryk Wierzbowski
}

Chair of Logistics, Faculty of Economics, University of Gdańsk, Poland

\section{APPLICATION OF BLOCKCHAIN TECHNOLOGY IN INFORMATION MANAGEMENT IN SUPPLY CHAINS}

\begin{abstract}
The aim of the article is to present the essence of information logistics in supply chains including a review of the literature referring to the information management strategy. The information is presented as one of the key resources of enterprises. The great importance of efficient and effective exchange of information is identified as a key factor in the context of building partner relations within supply chains. The article also presents the way in which the blockchain technology works and the possibilities of using it. Projects in which the blockchain technology will be used and which will refer to information management within the supply chains are also presented. An already existing application tool using the blockchain technology is also discussed. Owing to this, benefits derived from using tools based on the blockchain technology to improve information management within supply chains are identified.

Keywords: information logistics, supply chain, supply chain management, partnership, blockchain technology, application platforms
\end{abstract}

\section{Introduction}

Globalization, changes occurring in the economic environment, growing competition and more demanding requirements of customers as regards a higher service level are the main determinants stimulating the development of logistics services for modern economic processes. The increasing volume of flows of goods on global markets leads to a greater complexity of relations between enterprises operating within supply chains. Wishing to attain a competitive advantage, economic entities operating in the contemporary realities are forced to incessantly search for solutions aimed at more efficient and more effective operation of logistics services for 
manufacturing and transport processes. One of the basic ways to develop effective supply chains has been to build partnership relations between enterprises.

A very substantial role in supporting economic processes within supply chains is played by information management systems. Information is currently one of the key resources of enterprises. Efficient acquisition and processing of information is one of the basic factors increasing the efficiency of logistics activities. Continuous improvement and development of modern information systems directly reflects the realities and directions of development of the modern economy, showing the importance of information management within the supply chains.

The aim of the article is to present the possibilities of using the blockchain technology in information management of supply chain operations.

\section{Partnership as a key factor in the development of supply chains}

A supply chain is defined as any activity related to the movement and transformation of goods and the information accompanying these processes. In the case of supply chains, it is necessary to consider activities related to the flows and transformation of products starting from the point where raw materials are extracted, until the final product is supplied to the end consumer. All the intermediate phases of movement and creation of the product value should be taken into account, as well. All the activities within the supply chain involve also satisfying the requirements of the operation profitableness, efficiency and effectiveness. Should the cooperating entities wish to attain this objective, they would need to focus on improving the mutual relations (links) throughout the entire product delivery cycle. Management flows in a supply chain are currently perceived as one of the strategic areas of business operation of enterprises (Chaberek, 2002). Certain assumptions should be made to define the supply chain concept. For this reason, the author assumes that a commodity chain is a group of enterprises working together at processes related to the manufacture of specific goods or material groups. Specific goods including, but not limited to, raw materials, components, spare parts or semi-finished products incessantly flow at the contact points of commodity chain links. The physical movement of goods is always accompanied by a certain information resource. If processes related to flows of this type are to be performed effectively and efficiently, they must be accompanied by logistic services. The relationships having been presented in this way, it is concluded that the commodity chain is served by specific logistic processes that can be systemically called a logistic chain. If this line of thought is employed, it can also be said that the commonly accepted and applied concept of the supply chain reflects the coexistence of commodity chains and the accompanying logistic processes (Chaberek, 2015a).

The evolution associated with the implementation of logistics processes is inextricably linked to the development of strategies relating to the partnership between entities involved in flows of resources. In response to the growing global competition and the increasingly progressive shortening of product life cycles, enterprises need to pay more attention to the integration of activities within supply chains. Partnership in supply chains is a specific relationship between 
the cooperating enterprises. This relation should be characterized primarily by mutual trust, openness and a mutually accepted division of risks and benefits among all partners. The ability to define and improve components of processes related to mutual cooperation is crucial in improving the efficiency of activities carried out within supply chains. According to the author, the most beneficial form of partnership is P3. Chaberek defines it as establishing cooperation whereby each organization perceives the partner's activities as a natural extension of their business. Establishing such a strong partnership, enterprises that are links in the supply chain must analyse the impact of the regulators and external factors that may affect the formation of such mutual relations (Chaberek, 2015b). The most vivid challenges for optimum organization of flows of goods and information are the following (Christopher, 2000):

- new rules of competition, competition between entire supply chains;

- increasing significance of management related to the sphere of customer service;

- globalisation of the industry;

- the need to compress the time of activities;

- organization of processes related to the product quality control;

- improvements related to the transparency of operations in the supply chain;

- improving the flow of information in the supply chain.

According to the author, the above presented aspects of management activities should be a specific determinant for a template of actions to be taken when implementing new solutions in the supply chain management. Referring to problems formulated in such a way, it becomes increasingly obvious that enterprises cooperating within supply chains have a chance to survive only when they are able to introduce innovations to become a component of their current and future operations, at the same time improving the processes of integration and coordination of jointly undertaken activities.

\section{Information as a resource in the supply chain}

In addition to physical flows of goods there are also flows of information between participants in supply chains. In addition to the work, capital and land, it is information that has become one of the most important resources managed by enterprises. The dynamic development of the world based mainly on the growing importance of modern technologies determines the situation in which enterprises that do not have adequate information resources have no chance of gaining a competitive advantage. However, business entities may have a problem with incompetent use of information resources. In such a situation, appropriate logistics is required for information resource management to achieve the company's goals, and thus gain a competitive advantage (Weiland, 2016). The competitive advantage these days is gained chiefly through cooperation of partners who jointly plan and implement projects aimed at delivering goods to the end consumer. Hence, supply chain links should efficiently provide each other with information regarding customer needs, customer requirements, stock levels, manufacturing plans and demand for the goods that they produce (Wieczerzycki, 2009). Having access to relevant information, all 
participants to the exchange have greater knowledge about the processes carried out jointly. This makes it possible to solve the emerging problems effectively, respond to the market changes faster and efficiently respond to the requirements of customers related to their needs. Reliable information is also a resource necessary to draw up action plans and build a future strategy for managing the flows of resources. Therefore, enterprises continuously develop and improve their IT systems to ensure access to reliable data. Nevertheless, these systems support integration and improve the organization of supply chains, enabling appropriate planning and making the right decisions regarding coherent goals and effective coordination of activities (Ciesielski, 2010).

One of the most probable ways to develop the management of information resources in supply chains is the increasingly widespread use of IT technologies. They help efficiently and effectively support communication over long distances. They also make it possible to replace paper documents, which are still very common, with databases collected and processed in an electronic form. When ICT technologies are adapted in the supply chain management, it is possible to reduce the spatial, time and cost constraints which are barriers to establishing cooperation and running a business. Thus, taking into account the objectives and principles of supply chains operation which are based on partnership, the desired outcome is to combine individual information management modules which are increasingly often used by mining, manufacturing and trading enterprises (Ciesielski, 2010).

Hoverer, investments in IT technologies which improve business management do not always result in automatic improvement in performance. When investigating the reason for failing to successfully implement information technologies which would translate into better efficiency of management processes, a scheme for effective application of IT in business was discovered. Enterprises achieving growth effects resulting from implementation of IT technologies decided to make certain simplifications to their portfolios of specialized applications striving at the same time to create and use one integrated application platform. Such a platform reflects the operating system of a single computer. Fragmentary solutions included in the structure of such a platform are standardized. Owing to this, integrating many software components becomes even simpler whereby the risk of separating the information contained in separate technology silos can be eliminated. The activity aimed at integrating individual components of application platforms creates possibilities of a free data flow between the users of such systems. The role of such IT management systems is currently most frequently played by the ERP software. The use of specific technologically-engineered management systems based on information technologies is becoming one of the key foundations to go one step further in the management of material and information resources. This is done by extending the existing IT infrastructure to include the environment of the enterprise. The ERP class platforms had to be joined by platforms targeted at solving problems related to customer service and transport in supply chains for management decision-makers to be able to take into account what is happening in the environment of the enterprise. It was the need to illustrate the economic environment of individual links in the supply chain that made the ERP, CRM and SCM systems coexist with each other (Samól, 2012). 
Information in an information flow concept structured in this way, where ERM, CRM and SCM systems are jointly used via the Internet, can be immediately accessed by all the cooperating entities. Thus, the two streams, the physical distribution of goods and the flow of information can be separated. The decision-making processes are significantly shortened owing to such separation. When using the Internet, the geographical distance is not an issue, and the physical location of data processing does not matter. It also gives the possibility of developing a centralized information processing system while eliminating at the same time the flow of data through intermediate links of supply chains. The possibility of processing information on a global basis provides better conditions for optimising the processes of enterprises working together within a supply chain (Cellary, Strykowski, 2002).

State-of-the-art IT systems that can be applied to logistics should improve and support the processes of physical flows of goods, through enhancements related to the provision of information. To fulfil the task, IT systems should be based on databases being sets of items of information covering the environment of logistics processes taking place to support the main processes. In order to effectively move goods in time and space, the enterprise should have information (Szymonik, 2011) which is:

- correct, consistent with the actual physical condition;

- reliable, the sources of its origin should not arouse any doubts;

- selective, satisfying the user's need for information in a specific area of interest;

- complete, to the extent that an optimal decision can be made with the amount of available information;

- available on time, as expected by the system user;

- useful, supporting decision-making by logistics managers.

Appropriate conditions for the collection of information should be provided to be able to guarantee access to the above described relevant information to include (Szymonik, 2011):

- a detailed description of products, materials from which they were made and their life span;

- marking products with bar codes or electronic markers to be able to distinguish them in an unambiguous manner and automatically identify them;

- the ability to track products in real time, at any time during storage or relocation, so that the location, quantity, parameters and the type of goods can be determined.

In practice, the best tool for gathering information resources is Automatic Data Capture (ADC), which usually employs specific techniques of description of goods on information carriers. The most common information carriers used in logistics include tools such as: the group of optical signs to which bar codes are assigned and the group of electromagnetic carriers to which tags, electronic labels read using the RFID technology and biometric signs, e.g. watermarks are assigned (Szymonik, 2011). 


\section{Blockchain technology and its possible applications}

According to the European Commission the blockchain technology is supposed to significantly influence the transformation of business models in such areas as: healthcare, insurance, energy, intellectual property rights management, public administration and logistics. When the project called Observatory and Blockchain Forum was launched, it confirmed the extent to which the blockchain technology can change IT systems supporting management in various types of organizations. This initiative of the European Commission, supported also by the European Parliament, aims to highlight the most important advances in the field of technology development and to support entities interested in developing and using the blockchain technology in their operations (rp.pl, 2018).

The first application of the technology was the launch of the Bitcoin cryptocurrency in 2009, the value of which is based on the computing power, in contrast to other currently functioning currencies, the value of which has some reflection in the gold parity, state or international regulations. Less than a year ago the value of 1 Bitcoin exceeded the price of an ounce of gold (about PLN 4.330) which is the best way to illustrate how strong a currency based on the blockchain technology can become. Blockchain is a concept that is usually translated into Polish as "łańcuch bloków". As mentioned before, it was used for the first time as the basic value of the Bitcoin cryptocurrency. The blockchain application involved public recording of transactions conducted with the used of the currency. The chain is saved chronologically, it is shared among all the currency users. Literally speaking, a blockchain if made of chains of blocks also defined as blocks of information linked with each other into chains, where each successive link depends on the preceding one. Thus, the technology allows each of its users to have full information which is in the system database whereby it is possible to create a completely dispersed and decentralized data register. Owing to theses specifics of data collection, it is not possible to modify or falsify the information contained in the data block (jagiellonski24.pl, 2018).

It is the notion of dispersed databases that should be used to better understand the operation of the distributed registers technology, as it is also this Polish name that is used when referring to the blockchain technology. Such databases are used mainly to store information. On the other hand, information concerns transactions conducted between entities operating on the market. The original data stored in blocks is the basis for writing each subsequent block of the register to which a time stamp is attached. In addition to the time stamp, the process of creating a new block of data takes into account the imprint of the previous block and confirmation of the reliability of the changes made by other participants to the transaction. Owing to such a system of processing, it can be concluded that subsequent transactions lead to the formation of subsequent data blocks, which together with the previous ones form an information chain that is a large register of information. As the information database concerning transactions is of a public nature, hence, it is not possible to modify the historical data, as it would be reflected in all the subsequent blocks following the block in which the information would be modified (Garrett, 2017). For the very idea of a blockchain, it is also important to maintain a joint and collective 
transaction register. The database itself has a digital form and it is distributed over the network in identical copies. The data chain technology works through a peer-topeer network, so it does not use databases based on central computers. Therefore, every computer with access to the Internet has the right to participate in the transmission or authentication of information related to completed transactions (lazarski. pl, 2018). When describing the blockchain technology system, reference should be also made to the credibility of the authentication process. Every new item of information that is sent to the public transaction register has to be properly encrypted for which a pair of public and private keys is used. The keys themselves are electronic signatures of a kind, generated with the use of cryptography. The public key is best compared to the recipient's correspondence address, while the other private key can be identified as a password to confirm the authenticity of the data and to read the previously encrypted content. The private key is also a peculiar unique signature of the sender of information containing the content of the change introduced, its time and the identifier of the person who made the modification. The private key is generated by means of a special cryptographic algorithm, it is also unique for each set of data sent by a user or a computer. The need for continuous synchronization and updating of a distributed database may give the impression of being a nuisance. However, authorizations of the credibility of information do not have to be entered by humans. It is also computers or other devices being components of the system (such as e.g. machines used in a technology park of a factory manufacturing goods) responsible for the creation of new information blocks that can be used to confirm the authenticity of data. Based on the calculations made, machines or computers can 'vote' for the database version, which is most up-to-date according to them, being therefore also the most reliable one. Using such 'democratic elections', where the decision on the credibility of the new information block version is made by a majority of machines, it is very easy to improve the system of verifying the authenticity of information contained in data blocks. Such a system may also enable a database containing a lot of information to function in an efficient way, being at the same time a dispersed base characterized by universal access to information for all entities participating in transactions concerning flows of goods (jagiellonski24.pl, 2018).

\section{Blockchain technology application projects for information management in supply chains}

An example of applying the blockchain technology in information management within supply chains is the joint project of DNV GL and VeChain. The venture is aimed at developing a new Digital Assurance Concept, based on an application platform created basing on the blockchain technology. DNV GL is an organization certifying management systems by performing security audits of the conducted operations. By providing consulting services, GNV GL enables companies to ensure sustainable development of business, basing their services on applying international 
standards such as ISO $45001^{1}$ or ISO 13485:2016 2 . The main mission of the organization is to protect life, environment and property (dnvgl, 2018). VeChain is a platform based on the blockchain technology in which the medium of exchange is the VEN digital currency. The main goal of the organization is to develop an application platform enabling the creation of secure and transparent contracts entered into by enterprises which are links in global supply chains. One of the partners of VeChain is the Chinese government. In its operations, the platform focuses mainly on developing a business ecosystem, where an efficient and transparent information flow system is supposed to form a basis for strengthening the partnership relations between supply chain links (coincentral.com, 2018). The purpose of cooperation between DNV GL and VeChain is to develop a tool to improve the management of flows of goods and the accompanying information. The tool will also improve processes related to identification of transported products. The reliability of information concerning the quality of goods will also increase, whereby it will be possible to measure customer satisfaction more effectively. The tool created by partners can be used in the food, clothing, power, high-tech and automotive industries. Enterprises very often turn to third parties to efficiently manage the flows of goods and information in their business. Working together, organizations wish to provide their customers with the possibility to independently verify the quality, effectiveness and efficiency of processes related to the manufacture and movement of goods using an application platform which can operate owing to the blockchain technology. The tool is supposed to allow tracking of goods, raw materials and semi-finished products in real time. The technology is supposed to be based chiefly on peaking the information stored in RFID tags, NFC chips and QR bar codes. When such technical tools are used, it is possible to collect complete information on a single product. The product history will include data related to all manufacturing, storage and transport processes carried out. This will also make it possible to efficiently determine the current condition and quality of the product. The information included in the product history will be automatically peaked and later made available to all enterprises involved in creating the product value. In this way transparency and reliability of the collected data will be possible with simultaneous common access to such data by all authorized and interested parties (PR Newswire US, 2018).

Another example of cooperation aimed at improving information management using the blockchain technology is the cooperation between Moller-Maersk and IBM. Moller-Maersk is the largest enterprise in the world in the shipping and global trade services industry, with the main activity being the organization of container and intermodal transport including comprehensive logistics services (maerskline.com, 2018). IBM is a company manufacturing products and providing services in the high-tech industry in the broad sense of the term. IBM supports the activities of enterprises in the management of resources, risk, compliance, performance, planning, business analytics and application of IT technologies (maersk.com, 2018). The joint project is aimed at developing a system of handling international transport processes based on chains of data blocks in the blockchain

\footnotetext{
1 An ISO standard referring to the occupational safety and health management system.

2 An ISO standard applying to the medical product industry concerning quality management.
} 
technology. At the initial stage of development, the system is supposed to play the role of a tool for registration and management of shipments transported by sea. The main reason for the cooperation between Maersk and IBM is the observed gap in the services sector related to cargo transport management systems and related shipping processes. The main motive for cooperation is an attempt to reduce the use of paper documentation related to transport and forwarding. According to Maersk representatives of a logistics service process related to movement of an average cargo currently involves of about 30 people and nearly 200 process and communication steps. Such a state of affairs is the reason why the cost of preparing the documentation alone and completing all formalities becomes very high, representing on average approx. $20 \%$ of the actual cost of transporting an average cargo (itwiz. $\mathrm{pl}$, 2018). When a new data logging system based on the blockchain technology is used, it will ultimately integrate whole supply chains into one digital platform. Owing to such a platform, participants to the exchange will be able to share all the information about the products they manufacture and the required flows of goods in a safe and digital way along the entire supply chain length. The platform developed by Maersk and IBM is also supposed to be a source of information for entire industry sectors and final recipients of products. When the solution of Hyperledger Fabric from the Linux Foundation is used, all information on transactions will be available only to the relevant entities being the trading parties to such transaction. Authorized entities, responsible for processes of creation and flows of goods will be allowed to overwrite the information in new data blocks. Hence, the platform is supposed to enable joint work of many trading partners and give a uniform view of the transactions carried out, while maintaining specific details of the data, their privacy and confidentiality (maersk.com, 2018). The platform itself has two basic functionalities for tracking the product itself and the documentation related to its transport. The pilot application of the platform having been fully implemented by its partners, Maersk intends to commercialise the service created jointly with IBM. Extending of the use of the platform based on the blockchain technology is intended to include such enterprises interested in this system as: Procter \& Gamble, APM and General Motors. Hence, the project representatives count that other transport companies, commodity exchanges, port operators and customs services will be interested in implementing and using the project. Already now interest in the project has been expressed by entities providing port and customs services in the US, the Netherlands, Singapore and the Chinese province of Guangdong (itwiz.pl, 2018). The example of cooperation between IBM and Maersk shows how extensive the application of the blockchain technology in logistics can be. The mechanism ensuring a reduction in the operating cost interrelated with a reduction in paper documentation and the costs attributed to its flow indicates that all documents related to container trading can be digitised. It also shows the great possibilities of tracking shipments in real time, which can also bring significant benefits to the supply chain management (Ksheri, 2018). An example of cooperation of a high-tech enterprise and a transport and forwarding company shows a great opportunity to improve processes related to the collection, storage and sharing of information accompanying the movement of products 
while at the same time reducing the costs by limiting the use of paper documents and providing a possibility of sharing information with all the links in supply chains.

The solution applied by the Wal-Mart supermarket chain is a confirmation that application of the blockchain technology in the management of global supply chains is not just about plans but that it is reality. Wal-Mart is chiefly a retail trader. It a trading giant with a network of 11,600 retail stores under 59 different banners in 28 countries and e-commerce websites in 11 countries, serving around 260 million customers each week, while employing 2.3 million employees (corporate.walmart.com, 2018). The product range of Wal-Mart stores includes but is not limited to products in such categories as: home, electronics, clothing and jewellery, health and beauty, toys, video games, food, medicines, automobiles, home furnishings, gifts, pets, garden and much more (walmart.com, 2018). Wal-Mart has introduced the 'Smart Package' application tool which is tracking goods using RFID tags and barcodes with a simultaneously dispersed data structure in the blockchain technology. The reason for introducing the product tracking system is first of all care for the quality of products which should result in increased customer safety. The solution improves the processes of identifying the origin of goods in cases of detecting defective products and allows identifying the flow section where the product was damaged. The solution is also supposed to preclude human errors by preventing shipment of goods with quality defects. Product originality verification is another issue with which the tool introduced by Wal-Mart is related. It is estimated that $20-30 \%$ of the supplied products may be counterfeit to a smaller or larger extent. The solution is based on the use of unique product identifiers including information about their specific attributes. This information is modified and updated by all commodity flow agents along the entire supply chain (trans. info, 2018). In addition to the information on the product itself, subsequent supply chain links also update information on the condition of its packaging, environmental conditions of transport and exact location. The 'Smart Package' application itself is described in the patent application as a recorder of key addresses along the supply chain containing information on the seller's address, the courier's address and the buyer's private address. In addition to the current application the package will be used in the future also with modern means of transport such as autonomous vehicles and unmanned drones (cointelegraph.com, 2018). In addition to the 'Smart Package' application, Wal-Mart was already involved in the development of a technology for tracking products based on the blockchain technology at an earlier date. In collaboration with IBM and jointly with the world's largest suppliers of food products such as: Kroger, Nestle, Golden State Foods, Tyson Foods, McLane Company, Unilever, Dole, and McCormick and Company, Wal-Mart decided to develop a tool to reduce the time needed to locate sources of food-borne diseases. A consortium comprising such a large group of companies began to operate in 2017. The cooperation was coordinated through an integrated corporate-class platform based on the blockchain technology. If the project is successful, it is expected to provide significant improvements in security and traceability of threats by reducing the time needed to verify the sources of contaminated food, from several weeks down to even several seconds. The tool which is based on a dispersed transaction data register is supposed to bring savings to world 
food suppliers by improving the process of tracking their products. The better efficiency in terms of safety is aimed at reducing not only the costs associated with the immediate threat to the health or even life of customers, but also the costs related to withdrawing defective products from shelves in stores. The cost reduction also applies to protection against the loss of value of products that are potentially at risk of contamination. The process of verifying the source from which the defective product batch originates, which takes a very long time at the moment, may lead to a decrease in the demand for products and, consequently, falling prices of all articles in a given sector, even those of the highest quality (coindesk.com, 2018). During the initial phase of testing the tool developed by the cooperating companies, the products subjected to comprehensive tracking were pork imported from China and mango fruit originating from the US. These tests confirmed the potential for cost reduction and elimination of supplies of contaminated goods. It also confirmed the measurable benefits of applying this solution to other products. The tests also showed significant differences in the time of verification of product sources, the quality of which was not in line with the expectations of distributors or customers, between the entities participating in the project and their other competitors which needed much more time to verify the sources of the problem related to the quality or contamination of the product (gazeta online, 2016). Therefore, the above mentioned organizations, as part of their cooperation, want to create an application based on specific standards and methods of gathering information using the blockchain technology. This is aimed at increasing the level of safety and authenticity of the origin of food products and ensuring full traceability of the product and the place of its origin. This cooperation is also supposed to provide brand owners with sufficient privacy of data while strengthening the cooperation within global supply chains (forbes.com, 2018).

\section{Conclusions}

Information logistics is one of the key factors creating a competitive advantage of modern supply chains. In the author's opinion combining the automatic product tracking technology with the possibility of providing easily accessible and highly reliable information, stored and made available in subsequent blocks of the blockchain technology data, is an excellent solution to problems related to management of information within supply chains. The partner relations of all supply chain participants can be closer owing to an efficient information flow system. The supply chain links, starting from miners of raw materials, Tier 1 and Tier 2 suppliers, manufacturers, assembly plants, ending with the final consumer of products will be able to work together even more efficiently and effectively owing to the application platform. Quality control of products covering their composition, manufacturing processes, transport and warehousing systems can eliminate the procedure of counterfeiting and decreasing the quality of goods. The application platforms also offer a great chance of reducing the use of paper documentation regarding production and transport processes which at the same time would reduce the cost of business operations. On the basis of the conducted 
analysis and the cited examples, the author has concluded that the information systems and application platforms based on the use of blockchain technologies have a high chance of development and widespread use in the field of information logistics and in the sphere of supply chain management.

\section{References}

Cellary, W., Strykowski, S. (2002), Ewolucja tańcucha dostaw w gospodarce elektronicznej [Supply Chain Evolution in Electronic Economy], In: Rutkowski, K. (Ed.), Logistyka On-line [On-line Logistics], collective work, PWE, Warsaw, pp. 49-50.

Chaberek, M. (2015a), Logistyczne aspekty bezpieczeństwa [Logistics Aspects of Security], Zeszyty Naukowe Uniwersytetu Gdańskiego. Ekonomika Transportu i Logistyka [Research Bulletins of the University of Gdańsk. Transport Economics and Logistics], 56, pp. 26, 51-53.

Chaberek, M. (2015b), Makro- i mikroekonomiczne aspekty wsparcia logistycznego [Macroand Micro-economic Aspects of Logistics Support], Publishing House of the University of Gdańsk, Gdańsk, p.43.

Christopher, M. (2000), Logistyka i zarządzanie łańcuchem dostaw - Strategie obniżki kosztów i poziomu ustug, wydanie II [Logistics and Supply Chain Management - Cost Reduction and Service Level Strategies, $2^{\text {nd }}$ edition], Polish Logistics Advisory Centre, Warsaw, pp. 23-31.

Ciesielski, M. (2010), Łańcuch dostaw [Supply Chain], In: Ciesielski, M., Długosz, J., Strategie tańcuchów dostaw [Supply Chain Strategies], collective work, PWE, Warsaw, p. 28.

coincentral.com (2018), What is VeChain Thor? Available from https://coincentral.com/ vechain-thor-beginner-guide/ [Accessed 28 March 2018].

coindesk.com (2018), Walmart, Kroger \& Nestle Team with IBM Blockchain to Fight Food Poisoning. Available from https://www.coindesk.com/walmart-kroger-nestle-team-wit h-ibm-blockchain-to-fight-food-poisoning/ [Accessed 28 March 2018].

cointelegraph.com (2018), Walmart To Implement Blockchain-Based Delivery System. Available from https://cointelegraph.com/news/walmart-to-implement-blockchain-base d-delivery-system [Accessed 28 March 2018].

corporate.walmart.com (2018), Information on the Wal-Mart store from the website. Available from https://corporate.walmart.com/ [Accessed 28 March 2018].

dnvgl.com (2018), The business profile of DNV GL. Available from https://www.dnvgl.com/ [Accessed 28 March 2018].

forbes.com (2018), IBM \& Walmart Launching Blockchain Food Safety Alliance In China With Fortune 500's JD.com. Available from https://www.forbes.com/sites/rogeraitken/2017/12/14/ ibm-walmart-launching-blockchain-food-safety-alliance-in-china-with-fortune-500s-jdcom/\#1b6257117d9c [Accessed 28 March 2018].

Garrett, R. (2017), How Blockchain Is Transforming the Supply Chain, Supply and Demand Chain Executive, 18(2), pp. 10-14.

gazeta online (2016), To speed up food recalls, Walmart taps blockchain. British Library Document Supply Centre Inside Serials \& Conference Proceedings, EBSCOhost, Business week, online, 20 [Accessed 30 April 2018].

ibm.com (2018a). Available from https://www.ibm.com/products [Accessed 28 March 2018]. ibm.com (2018b), IBM, Maersk Joint Blockchain Venture to Enhance Global Trade. Available from https://www.ibm.com/blogs/think/2018/01/maersk-blockchain/ [Accessed 28 March 2018]. itwiz.pl (2018), Czy Blockchain okaże się sposobem na uproszczenie globalnej logistyki? [Will Blockchain Prove to be a Way to Simplify Global Logistics?]. Available from https:/itwiz. $\mathrm{pl} /$ czy-blockchain-okaze-sie-sposobem-na-uproszczenie-globalnej-logistyki/ [Accessed 28 March 2018]. 
jagiellonski24.pl (2018), Blockchain dla laików. Na czym polega technologia, która ma zmienić świat? [Blockchain for laymen. What is the Technology that is Supposed to Change the World About?]. Available from http://jagiellonski24.pl/2017/06/20/blockchain-dla-laikow-na-czy m-polega-technologia-ktora-ma-zmienic-swiat/ [Accessed 26 March 2018].

Ksheri, N. (2018), Blockchain's roles in meeting key supply chain management objectives, International Journal of Information Management, 39, pp. 80-89.

lazarski.pl (2018), Co powinniśmy wiedzieć o technologii blockchain? [What Should We Know about the Blockchain Technology?]. Available from https://www.lazarski.pl/pl/wydzialy-i-jednostki/instytuty/wydzial-ekonomii-i-zarzadzania/centrum-technologii-blockchain/ co-powinnismy-wiedziec-o-technologii-blockchain/ [Accessed 26 March 2018].

maersk.com (2018), Maersk and IBM launch digital joint venture. Available from https://www. maersk.com/stories/maersk-and-ibm-launch-digital-joint-venture [Accessed 28 March 2018].

maerskline.com (2018), Business profile of Moller-Maersk. Available from https://www.maerskline.com/about/profile [Accessed 28 March 2018].

PR Newswire US (2018), DNV GL Partners With Blockchain Expert VeChain to Increase Transparency From the Factory to the Consumer, Regional Business News, January.

rp.pl (2018), The European Commission supports the blockchain technology. Available from http://www.rp.pl/Telekomunikacja-i-IT/302019924-Komisja-Europejska-wspiera-te chnologie-blockchain.html [Accessed 26 March 2018].

Samól, D. (2012), Wartość technologii przetwarzania informacji w zarządzaniu logistyka przedsiębiorstwa [The Value of Information Processing Technologies in Business Logistics Management], In: Brdulak, H., Logistyka przyszłości [Logistics of the Future], collective work, PWE, Warsaw, pp. 183-185.

Szymonik, A. (2011), Logistyka i zarządzanie łańcuchem dostaw, cz. 2 [Logistics and Supply Chain Management, part 2], Difin, Warsaw, pp. 134-136.

trans.info (2018), Blockchain "czarnym koniem" logistyki? [Is Blockchain a 'Dark Horse' of Logistics?]. Available from https://trans.info/blockchain-czarnym-koniem-logistyki-83455 [Accessed 28 March 2018].

walmart.com (2018), Wal-Mart store website. Available from https://www.walmart.com/ [Accessed 28 March 2018].

Weiland, D. (2016), Logistyka informacji jako podstawowy element w budowaniu przewagi konkurencyjnej w e-commerce [Information Logistics As a Basic Component in Creating a Competitive Advantage in E-commerce], Economic Studies. Research Journal of the University of Economics in Katowice, 306, p. 100.

Wieczerzycki, W. (2009), Informatyczne wspomaganie zarządzania łańcuchem dostaw [IT Support of Supply Chain Management], In: Długosz, J. (Ed.), Nowoczesne technologie w logistyce [Modern Technologies in Logistics], collective work, PWE, Warsaw, pp. 66-67.

Witkowski, J. (2010), Zarządzanie łańcuchem dostaw - Koncepcje, procedury, doświadczenia [Supply Chain Management - Concepts, Procedures, Experiences]. PWE, Warsaw.

\section{Corresponding author}

Patryk Wierzbowski can be contacted at: patryk.wierzbowski@ug.edu.pl 